lesions well, and subsequent MRI with pharmacologically induced erection more clearly delineated the lesions and their origin. This demonstrates that even for gross soft tissue lesions of the penis, there can be value added when this technique is employed. We agree with the conclusion of your letter, that MRI with pharmacologically induced erection should be considered in the setting of painful erections.

Competing interests: Authors declare no competing financial or personal interests.

\section{References}

1. Lucky M, McGuinness L, Floyd MS Jr. MRI use with artificial erection in cases of painful erections [letter]. Can Urol Assoc J 2014;8:394. http://dx.doi.org/10.5489/cuai.2489

2. Barber E, Domes T. Painful erections secondary to rare epithelioid hemangioma of the penis. Can Urol Assoc J 2014;8:e647-9. http://dx.doi.org/10.5489/cuaj.1833

3. Lucky M, McGuinness L, Floyd MS Jr, et al. Epithelioid haemangioma: A rare cause of painful erections and sleep deprivation. Int Urol Nephrol 2014;46:1747-50. http://dx.doi.org/10.1007/ s1 1255-014-0705-2

Correspondence: Dr. Evan Barber, College of Medicine, University of Saskatchewan, Saskatoon, SK; evan.barber@gmail.com

\title{
Microscopic hematuria and urothelial malignancy
}

\section{Sim Sai Tin, MD; ; Viroj Wiwanitkit, $M D^{\dagger}$}

*Medical Center, Shantou, China; 'Visiting professor, Hainan Medical University, China

Cite as: Can Urol Assoc J 2014;8(11-12):395.

http://dx.doi.org/10.5489/cuai.2440

Published online December 15, 2014.

K otb and Attia noted that "cystoscopy is highly recommended for young adult men, with significant levels of microscopic hematuria, due to the $20 \%$ incidence rate of associated urological malignancy." 1 In fact, there are several etiologies of microscopic hematuria. ${ }^{2}$ Using cystoscopy might be useful, however, it is questionable due to its invasiveness. There may be some useful additional tests for the differential diagnosis of other causes of hematuria, such as urine biochemistry and urine red cell morphology study. As noted by McDonald and colleagues, the use of urine cytology should be considered before deciding to use cystoscopy to investigate a patient with hematuria. ${ }^{3} \mathrm{~A}$ recent medical economics study concluded that "for low-risk patients the use of immediate cystoscopy could be avoided if cystoscopy were used for follow-up patients with a negative initial test using tumour markers and/or cytology." ${ }^{4}$

Competing interests: Authors declare no competing financia or personal interests.

\section{References}

1. Kotb AF, Attia D. High-grade microscopic hematuria in adult men can predict urothelial malignancy. Can Urol Assoc $J$ 2014;8:E481-4. http://dx.doi.org/10.5489/cuaj.1746

2. Sharp VJ, Barnes KT, Erickson BA. Assessment of asymptomatic microscopic hematuria in adults. Am Fam Physician 2013;88:747-54

3. McDonald MM, Swagerty D, Wetzel L. Assessment of microscopic hematuria in adults. Am Fam Physician 2006;73:1748-54.

4. Rodgers M, Nixon J, Hempel $S$, et al. Diagnostic tests and algorithms used in the investigation of haematuria: Systematic reviews and economic evaluation. Health Technol Assess 2006;10:iii-iv, xi-259.

Correspondence: Dr. Sim Sai Tin, Medical Center, Shantou, China; simsaitin@gmail.com

\section{Author response: Microscopic hematuria and urothelial malignancy}

\section{Ahmad M. Beltagy, MD; Doaa Attia, MD; Ahmed Fouad Kotb, $M D$}

Urology Department, Faculty of Medicine, Alexandria University, Alexandria, Egypt

Cite as: Can Urol Assoc J 2014;8(11-12):395.

http://dx.doi.org/10.5489/cuaj.2577

Published online December 15, 2014.

W e would like to thank Tin and colleagues ${ }^{1}$ for their interest in our publication. ${ }^{2}$ There are many etiologies of microscopic hematuria $(\mathrm{MH})$, other than urinary tract malignancy; however, the presence of dysmorphic red blood cells, proteinuria, casts and/or renal insufficiency or any other clinical indicator suspicious for renal parenchymal disease warrants concurrent nephrologic and urological workup. ${ }^{3}$ 